\title{
Pengaruh Debt Covenant, Ukuran Perusahaan, Leverage, Terhadap Konservatisme Akuntansi
}

\author{
Alya Noviyanti ${ }^{1}$, Mohammad Zulman Hakim ${ }^{2}$, Dirvi Surya Abbas $^{3}$ \\ Fakultas Ekonomi dan Bisnis Universitas Muhammadiyah Tangerang123 \\ e-mail: noviyantialya177@gmail.com (email korespondensi)
}

\begin{abstract}
Abstrak: Penelitian ini dilakukan untuk mengetahui pengaruh Debt Convenant, Ukuran Perusahaan, Leverage terhadap Konservatisme Akuntansi pada Sektor Consumer goods industri yang terdaftar di Bursa Efek Indonesia (BEI). Periode waktu penelitian yang digunakan adalah 3 tahun yaitu periode 2017-2019. Teknik pengambilan sampel menggunakan teknik Purposive sampling. Berdasarkan kriteria yang telah ditetapkan diperoleh 15 perusahaan. Jenis data yang digunakan adalah data sekunder yang diperoleh dari situs Bursa Efek Indonesia. Metode analisis yang digunakan adalah analisis regrensi data panel. Teknik analisis data menggunakan EViews 9.0. Hasil dari penelitian ini menyatakan. Debt Convenant dan Ukuran Perusahaan tidak berpengaruh terhadap Konservatisme Akutansi. Sedangkan Leverage berpengaruh positif terhadap Konservatisme Akuntansi.

Kata Kunci : Debt Convenant, Ukuran Perusahaan, Leverage dan Konservatisme Akuntansi
\end{abstract}

Konservatisme merupakan prinsip akuntansi yang jika diterapkan akan menghasilkan angka-angka laba dan aset yang cenderung rendah, serta angka- angka biaya dan utang cenderung tinggi. Banyak orang beranggapan bahwa konservatisme merupakan prinsip yang kontroversial karena konservatisme akan menghasilkan laporan keuangan akan terlihat tidak mencerminkan kondisi perusahaan yang sesungguhnya dan tampak bias (Erni, 2016; Afina, 2015; Ni Wayan, 2015). Selain itu, konservatisme akuntansi akan memperlihatkan kondisi yang bias mengenai situasi financial perusahaan, sehingga hal itu akan menghasilkan angka serta kualitas laba yang lebih rendah daripada sewajarnya. Penerapan dalam konsep konservatisme akuntansi dalam suatu prinsip akuntansi adalah perhitungan akuntansi akan mengakui adanya rugi yang kemungkinan terjadi, tetapi akuntansi tidak menerapkan hal serupa terhadap laba yang akan diperoleh (Febriana, 2016; Afina, 2015).

Salah satu skandal keuangan yang pernah terjadi terkait dengan konservatisme adalah skandal tentang BUMN yang memanipulasi laba pada laporan keuangannya. Perusahaan milik pemerintah diduga membuat laporan seolah-olah laba yang diterima lebih besar dari laba yang sebenarnya. Modus tersebut dilakukan dengan melaporkan pendapatan perusahaan yang sebetulnya belum masuk. Tujuannya, melambungkan laba perusahaan itu. Dengan dimikian, laba perusahaan tersebut terlihat besar dan direksinya bisa mendapat bonus yang besar pula (ekbis.rmol.co, 2013). Kasus yang terjadi pada BUMN tersebut menunjukkan manajemen tidak menerapkan prinsip konservatisme dalam laporan keuangan perusahaan, sehingga terjadi overstatement laba pada laba bersih. Dalam hal ini perusahaan dinilai menargetkan laba terlalu 
tinggi sehingga manajemen melakukan segala hal untuk memenuhi target tersebut dan mengabaikan nilai konservatisme.

Signaling theory menjelaskan bahwa pemberian sinyal dilakukan oleh manajer untuk mengurangi asimetri informasi. Manajer memberikan informasi melalui laporan keuangan bahwa mereka menerapkan kebijakan akuntansi konservastisme yang menghasilkan laba lebih berkualitas karena prinsip ini mencegah perusahaan melakukan tindakan membesarbesarkan laba dan membantu pengguna laporan keuangan dengan menyajikan laba dan aktiva yang tidak overstate. Di dalam praktiknya, yaitu manajemen menerapkan kebijakan akutansi konservatif dengan menghitung depresiasi yang tinggi akan menghasilkan laba rendah yang relatif permanen yang berarti tidak mempunyai efek sementara pada penurunan laba yang akan berbalik pada masa yang akan datang (Fala, 2007).

\section{METODE}

Perusahaan ini mengambil sampel Perusahaan sektor Consumer goods industri yang Terdaftar di Bursa Efek Indonesia Tahun 2017-2019)". Data yang digunakan dalam penelitian ini adalah data sekunder yang diperoleh dari situs resmi Indonesian Stock Exchange (IDX). Pengembalian sampel pada penelitian ini dengan menggunakan teknik purposive sampling yaitu pengembalian sampel berdasarkan kriteria tententu dari hasil pemilihan sampel dengan menggunakan Purposive Sampling terpilih 15 perusahaan yang memenuhi kriteria.

Tabel 1. Definisi Operasional Variabel

\begin{tabular}{|c|c|c|c|c|}
\hline No & Variabel & Dimensi & Indikator & Rasio \\
\hline 1 & $\begin{array}{l}\text { Konservatisme } \\
\text { akuntansi }\end{array}$ & $\begin{array}{l}\text { Konservatisme } \\
\text { didefinisikan sebagai reaksi } \\
\text { kehati-hatian } \\
\text { terhadap (prudent) } \\
\text { ditujukan untuk metidakpastian, } \\
\text { hak-hak dan kepentingan } \\
\text { pemegang } \\
\text { (shareholders) dan pemberi } \\
\text { pinjaman (debtholders) yang } \\
\text { menentukan sebuah } \\
\text { verifikasi standar yang lebih } \\
\text { tinggi untuk mengakui } \\
\text { goodnews } \\
\text { badnews daripada }\end{array}$ & $\begin{array}{l}\text { Market to Book } \quad=\frac{\text { harga pasar per saha }}{\text { nilai buku per saham }} \\
\text { Nilai buku per saham }=\frac{\text { TotalEkuitas }}{\text { jumlah saham beredar }}\end{array}$ & Rasio \\
\hline 2 & Debt Convenat & $\begin{array}{l}\text { Debt covenant akan } \\
\text { mendorong manajer untuk } \\
\text { mencapai kinerja terbaik } \\
\text { yang salah satunya juga } \\
\text { dilakukan melalui pemilihan } \\
\text { metode akuntansi yang } \\
\text { dapat mendukung tujuan } \\
\text { tersebut sehingga akan }\end{array}$ & $\begin{array}{c}\text { Debt Convenant }=\frac{\text { Total Liabilitas }}{\text { Total Asset }}\end{array}$ & Rasio \\
\hline
\end{tabular}




\begin{tabular}{|c|c|c|c|c|}
\hline & & $\begin{array}{lr}\begin{array}{l}\text { menghasilkan } \\
\text { keuangan yang laporan } \\
\text { konservatif. }\end{array} & \text { kurang }\end{array}$ & & \\
\hline 3 & $\begin{array}{l}\text { Ukuran } \\
\text { Perusahaan }\end{array}$ & $\begin{array}{l}\text { Ukuran perusahaan adalah } \\
\text { skala besar kecilnya } \\
\text { perusahaan yang dapat } \\
\text { diklasifikasi berdasarkan } \\
\text { berbagai cara, antara lain } \\
\text { dengan ukuran pendapatan, } \\
\text { total aset, dan total ekuitas } \\
\text { (Agustina \& Gede, 2017). }\end{array}$ & Ukuran Perusshasan = Log norms (Total Aset) & Rasio \\
\hline 4 & Leverage & $\begin{array}{l}\text { Leverage } \\
\text { penggunaan aset dan } \\
\text { sumber dana oleh } \\
\text { perusahaan yang memiliki } \\
\text { beban tetap. Leverage } \\
\text { diukur dengan debt equity } \\
\text { ratio (DER) dari hasil bagi } \\
\text { jumlah hutang dengan } \\
\text { jumlah ekuitas, berdasarkan } \\
\text { penelitian (Alhayati, } 2013\end{array}$ & DER $=\frac{\text { Total Hutang }}{\text { Total Modal Sendiri }}$ & Rasio \\
\hline
\end{tabular}

Penelitian ini dilakukan untuk mengetahui pengaruh Debt Convenant, Ukuran Perusahaan, Leverage terhadap Konservatisme Akuntansi pada Sektor Consumer goods industri yang terdaftar di Bursa Efek Indonesia (BEI). Periode waktu penelitian yang digunakan adalah 3 tahun yaitu periode 2017-2019. Teknik pengambilan sampel menggunakan teknik Purposive sampling. Berdasarkan kriteria yang telah ditetapkan diperoleh 15 perusahaan. Jenis data yang digunakan adalah data sekunder yang diperoleh dari situs Bursa Efek Indonesia. Metode analisis yang digunakan adalah analisis regrensi data panel. Teknik analisis data menggunakan EViews 9.0. Hasil dari penelitian ini menyatakan. Debt Convenant dan Ukuran Perusahaan tidak berpengaruh terhadap Konservatisme Akutansi. Sedangkan Leverage berpengaruh positif terhadap Konservatisme Akuntansi.

Tabel 2. Rangkuman Hasil Pengujian Metode penelitian

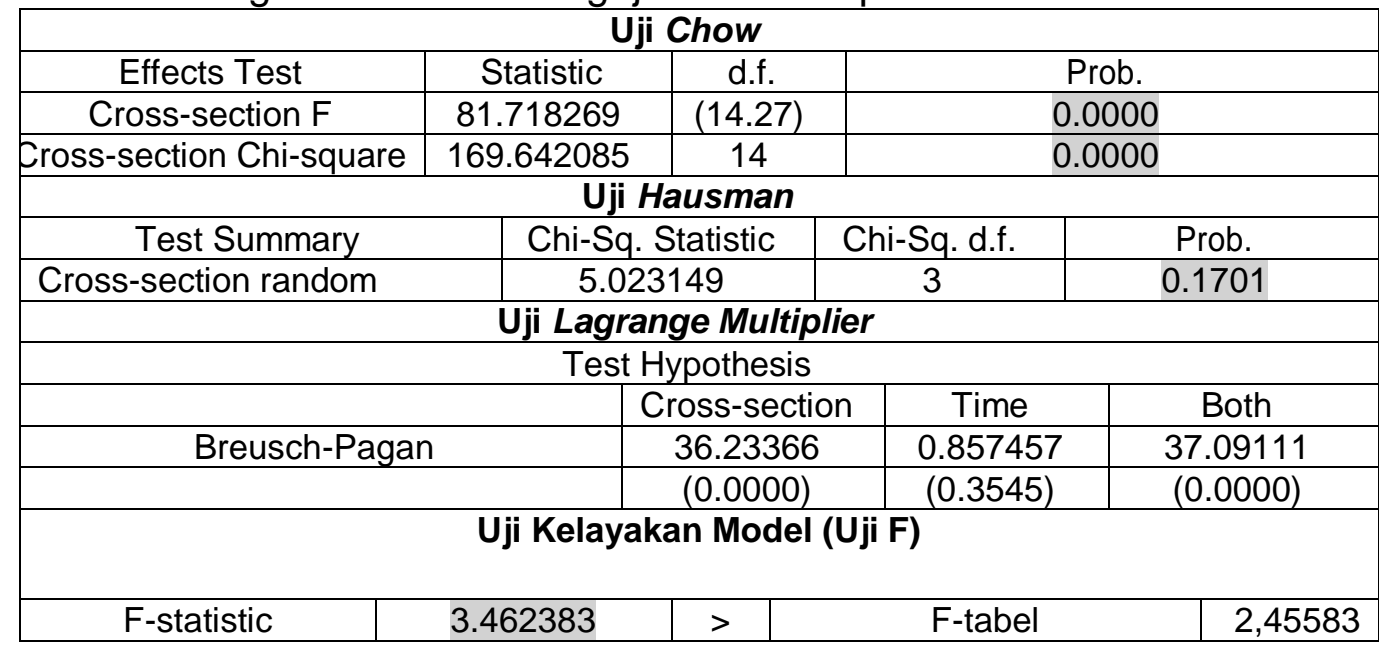




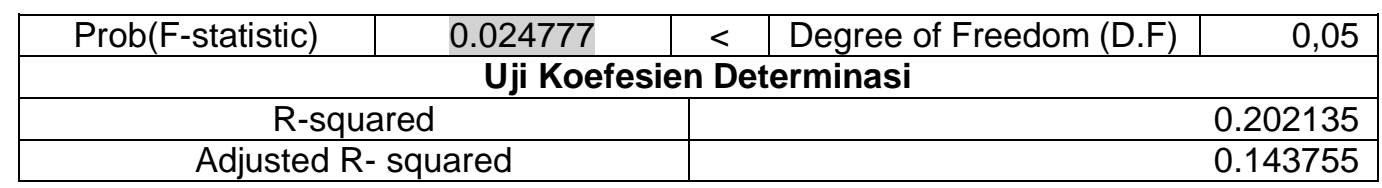

Sumber : Data diolah Eviews 9.0

Berdasarkan hasil perhitungan diatas nilai Probabilitas Crosssection $F$ dan Cross-section chi-square $<0,05$, maka dapat disimpulkan bahwa Fixed Effect Model (FEM) lebih layak digunakan dibandingkan Common Effect Model (CEM). Selanjutnya hasil uji hausman menunjukkan bahwa nilai Probabilitas Cross- section random $>\alpha(0,05)$, maka dapat disimpulkan bahwa Random Effect Model (REM) lebih layak digunakan dibandingkan model Fixed Effect Model (FEM). Dan terakhir hasil uji lagrange menunjukkan bahwa nilai Probabilitas Cross- section BreuschPagan < a $(0,05)$, maka dapat disimpulkan bahwa Random Effect Model (REM) lebih layak digunakan dibandingkan model Common Effect Model (CEM).

Setelah didapatkan model yang layak untuk digunakan dalam penelitian ini, maka pengujian selanjutnya adalah pengujian tentang asumsi klasik. Uji asumsi klasik adalah suatu persyaratan pengolahan data statistik yang harus dilakukan dalam pengolahan data analisis regresi jika jenis data yang digunakan adalah dengan pendekatan berjenis Ordinary Least Squared (OLS) dalam teknik estimasinya

Berdasarkan hasil Output Eviews 9 dalam tabel 2 tentang hasil output Uji Kelayakan Model (Uji F) menunjukkan bahwa nilai F-statistic sebesar 3.462383 , sementara Ftable dengan tingkat $\square \square=5 \%$, df1 $(\mathrm{k}-1)=$ 5 dan df2 $(n-k)=39$ di dapat $F$ tabel sebesar 2,45583 Dengan demikian Fstatistic $(3.462383)>F$ Tabel $(2,45583)$ dan nilai Prob(F-statistic) $0,024777<0,05$ maka dapat disimpulkan bahwa Ha diterima, maka dengan demikian dapat disimpulkan bahwa model dalam penelitian ini layak digunakan. Selanjutnya nilai Adjusted R-squared sebesar 0.143755, artinya bahwa variasi perubahan naik turunnya Konservatisme Akuntansi dapat dijelaskan oleh Debt Convenant, Ukuran Perusahaan, Leverage sebesar $14.3 \%$ sementara sisanya $85.7 \%$ dijelaskan oleh variable-variable lain yang diteliti dalam penelitian ini.

Hasil Penelitian

Tabel 3. Statistik Deskriptif

\begin{tabular}{|l|c|c|c|c|}
\hline & $\mathbf{Y}$ & $\mathbf{X 1}$ & $\mathbf{X 2}$ & $\mathbf{X 3}$ \\
\hline Mean & 0.108667 & 0.316222 & 1.096444 & 0.706667 \\
\hline Median & 0.050000 & 0.320000 & 1.110000 & 0.510000 \\
\hline Maximum & 0.490000 & 0.740000 & 0.150000 & 2.910000 \\
\hline Minimum & 0.010000 & 0.010000 & 0950000 & 0.150000 \\
\hline Std. Dev. & 0.115475 & 0.168796 & 0.040235 & 0.603531 \\
\hline Observations & 45 & 45 & 45 & 45 \\
\hline
\end{tabular}

Sumber : Data diolah Eviews 9.0 
Nilai Mean terbesar dialami oleh variable Ukuran Perusahaan (UP) yaitu sebesar 1.096444 , sementara Konservatisme Akuntansi memiliki niai mean terkecil yaitu 0.108667 .

Nilai Median terbesar dialami oleh variable Ukuran Perusahaan (UP) yaitu sebesar 1.110000 , sementara Konservatisme Akuntansi memiliki nilai median terkecil yaitu sebesar 0.050000 .

Nilai Maximum terbesar dialami oleh variable Leverage yaitu sebesar 2.910000 , sementara Konservatisme Akuntansi memiliki nilai maximum terkecil yaitu sebesar 0.0490000 .

Nilai Minimum terbesar dialami oleh variable Ukuran Perusahaan (UP) yaitu sebesar 0.950000 , sementara Variabel konservatisme Akuntansi dan Debt Convenant memiliki nilai minimum terkecil sebesar 0.010000

Nilai Std. Dev. (Standar Deviation) terbesar dialami oleh variabel Leverage yaitu sebesar 0.603531 yang berarti Leverage memiliki tingkat risiko yang lebih tinggi mengalami perubahan dibandingkan dengan variable-variable yang lain selama periode penelitian. Sementara variable Ukuran Perusahaan (UP) mempunyai tingkat resiko yang paling rendah, yaitu sebesar $0.040235 \mathrm{Hal}$ ini menunjukan bahwa variable Ukuran Perusahaan (UP) selama periode penelitian tidak terlalu fluktuatif..

Nilai Skewness yang memiliki nilai di atas 0 (nol) yaitu Konservatisme Akuntansi, dan Leverage yang berarti bahwa asimetri distribusi data disekitar mean tidak normal, sedangkan variabel Debt Convenant dan Ukuran Perusaan memiliki nilai disekitaran 0 (nol) yang berarti bahwa asimetri distribusi data disekitar mean bersifat normal.

Pada niai Kurtosis untuk variable Konservatisme Akuntansi, Debt Convenant, Ukuran Perusahaan, Leverage memiliki nilai kurtosis lebih dari 3 yang berarti bahwa ketinggian distribusi data tidak normal,

\begin{tabular}{|c|l|c|c|}
\hline $\mathbf{N}$ & \multicolumn{1}{|c|}{ Hipotesis } & Signifikansi & Hasil \\
$\mathbf{0}$ & & & \\
\hline 1. & $\mathrm{H}_{1}:$ Debt Convenat tidak mempunyai pengaruh yang & t-statistic & Ditolak \\
& signifikan dengan arah positif terhadap & 0.875971 & \\
& Konservatisme Akuntansi & Prob. 0.3861 & \\
\hline 2. & $\mathrm{H}_{2}:$ Ukuran Perusahaan tidak mempunyai pengaruh & t-statistic - & Ditolak \\
& yang signifikan dengan arah hubungan negatif & 0.072705 & \\
& terhadap Konservatisme Akuntansi. & Prob. 0.9424 & \\
\hline 3. & $\mathrm{H}_{3}:$ Leverage mempunyai pengaruh yang signifikan & t-statistic & Diterima \\
& dengan arah pengaruh positif terhadap & 2.276165 & \\
& Konservatisme Akuntansi & Prob. $0 . .0281$ & \\
\hline
\end{tabular}

Variabel Debt Convenant memiliki t-hitung sebesar 0.875971, dan nilai signifikan sebesar $0 . .0281$ yang berarti lebih besar dari 0,05. Dengan demikian bahwa variabel Debt Convenant berpengaruh tidak mempunyai pengaruh yang signifikan dengan arah positif terhadap Konservatisme Akuntansi. Sehingga H1 Ditolak.

Variabel Ukuran Perusahaan memiliki t-hitung sebesar 0.072705, dan nilai signifikan sebesar 0.9424 yang berarti lebih besar dari 0,05. Dengan demikian bahwa variabel Ukuran Perusahaan tidak mempunyai 
pengaruh yang signifikan dengan arah hubungan negatif terhadap Konservatisme Akuntansi.

Variabel Leverage memiliki t-hitung sebesar 2.276165, dan nilai signifikan sebesar 0.9424 yang berarti lebih besar dari 0,05. Dengan demikian bahwa variable leverage mempunyai pengaruh yang signifikan dengan arah pengaruh positif terhadap Konservatisme Akuntansi

\section{KESIMPULAN}

Penelitian ini dilakukan untuk mengetahui pengaruh Debt Convenant, Ukuran perusahaan, Leverage terhadap Konservatisme Akuntansi (Studi Empiris Sektor Consumer goods industri yang Terdaftar di Bursa Efek Indonesia Tahun 2017-2019)". dengan sample sebanyak 15 perusahaan dan periode waktu penelitian yang digunakan adalah 3 tahun yaitu periode 2014-2018, dan analisis data yang digunakan menggunakan analisis data panel. Berdasarkan analisis data yang dilakukan pada bab 4, maka dapat disimpulkan sebagai berikut :

Variable Debt Convenat tidak mempunyai pengaruh yang signifikan dengan arah positif terhadap Konservatisme Akuntansi.

Variable Ukuran Perusahaan tidak mempunyai pengaruh yang signifikan dengan arah hubungan negatif terhadap Konservatisme Akuntansi.

Variable Leverage mempunyai pengaruh yang signifikan dengan arah pengaruh positif terhadap Konservatisme Akuntansi.

\section{DAFAR PUSTAKA}

Eksandy, Arry. (2018). Pedoman Penulisan Skripsi Prodi Akuntansi. Universitas Muhammadiyah Tangerang

$\mathrm{Ni}$ Kd Sri Lestari Dewi 1 I Ketut Suryanawa2, 2014 PENGARUH STRUKTUR KEPEMILIKAN MANAJERIAL, LEVERAGE, DAN FINANCIAL DISTRESS TERHADAP KONSERVATISME AKUNTANSI

Aulia Ramadona 2016, PENGARUH STRUKTUR KEPEMILIKAN MANAJERIAL, STRUKTUR KEPEMILIKAN INSTITUSIONAL, UKURAN PERUSAHAAN DAN LEVERAGE TERHADAP KONSERVATISME AKUNTANSI

$\mathrm{Ni}$ Wayan Noviantari1 Ni Made Dwi Ratnadi2, 2015, PENGARUH FINANCIAL DISTRESS, UKURAN PERUSAHAAN, DAN LEVERAGE PADA KONSERVATISME AKUNTANSI

Dinny Prastiwi Brilianti, 2013, PENGARUH KEPEMILIKAN MANAJERIAL, KEPEMILIKAN INSTITUSIONAL, LEVERAGE DAN KOMITE AUDIT TERHADAP KONSERVATISME AKUNTANSI

Dita Yuliarti, 2017, PENGARUH LEVERAGE, UKURAN PERUSAHAAN, KEPEMILIKAN MANAJERIAL, UKURAN DEWAN KOMISARIS DAN PROFITABILITAS TERHADAP KONSERVATISME AKUNTANSI

Risa Dewi A'isya1 Mekani Vestari2, PENGARUH BONUS PLAN, DEBT COVENANT, POLITICAL COST, DAN LITIGATION RISK 
$\begin{array}{lccr}\text { TERHADAP } & \text { KONSERVATISME } & \text { AKUNTANSI } & \text { PASCA } \\ \text { KONVERGENSI } & \text { INTERNATIONAL } & \text { FINANCIAL } & \text { REPORTING }\end{array}$ STANDARDS

Utama, I.Y. 2015. Pengaruh Struktur Kepemilikan Manajerial, Leverage, Growth Opportunities, dan Ukuran Perusahaan terhadap Konservatisme Akuntansi. Skripsi. Universitas Islam Negeri Syarif Hidayatullah. Jakarta.

Septian, A. dan Y. D. Anna. 2014. Pengaruh Kepemilikan Manajerial, Ukuran Perusahaan, Debt Covenant, dan Growth Opportunities terhadap Konservatisme Akuntansi (Studi pada Sektor Industri Farmasi yang Terdaftar di Bursa Efek Indonesia Tahun 2008- 2012). Jurnal Publikasi Penelitian.

Alfian, Angga dan Arifin Sabeni. 2013. PENGARUH KEPEMILIKAN MANAJERIAL DAN DEBT COVENANT TERHADAP KONSERVATISME AKUNTANSI

Latifa Dinar Ayuningsih, 2Kania Nurcholisah, 3Helliana, 2013 PENGARUH DEBT CONVENT, KEPEMILIKAN MANAJERIALI, dan GROUTH OPPORTUNITIES TERHADAP KONSERVATISME AKUNTANSI

Anis Dwi Lestari1 2016 PENGARUH KEPEMILIKAN MANAJERIAL, LEVERAGE, GROWTH OPPORTUNITY, dan POLITICAL COST TERHADAP KONSERVATISME AKUNTANSI 